\title{
Strength and Micro-structural Properties of Wood Chips Composite Panel
}

\begin{abstract}
Timothy Denen Akpenpuun,* and Ridwan Gbadeyanka
The increase in activities in the wood-based industries has contributed greatly to deforestation, and this has consequently led to the development of new materials to substitute for the felling of trees. In this study, red Ironwood (Lophira alata) chips and cassava starch were used for the production of particleboard. Chip sizes of 0.85 and $1.7 \mathrm{~mm}$ and the dosage and types of binders (cassava starch, urea formaldehyde, and glutaraldehyde-modified cassava starch) were the variables. The ratio of wood chips to the binders was 1.0:1.5. The boards were formed in rectangular moulds. Water absorption, thickness swelling, flexural tests, and material characterisation (scanning electron microscopy) were performed. The data were subjected to analysis of variance. The panels produced with modified cassava starch had the best mechanical properties with the modulus of elasticity ranging from 5.9 to $32.3 \mathrm{~N} / \mathrm{mm}^{2}$ but had a higher thickness swelling values ranging from 3 to $59.4 \%$. There was a significant difference $(p<0.01)$ between the boards manufactured using plain starch and modified starch. These results showed that modified cassava starch is a better binding agent than plain cassava starch in terms of panel MOR and MOE. The developed particleboard can be used for indoor paneling, partitioning, and ceilings.
\end{abstract}

Keywords: SEM; Flexural; Particles; Properties; Starch; Wood; Waste

Contact information: Department of Agricultural and Biosystems Engineering, University of Ilorin, P.M.B. 1515, Ilorin, Nigeria; *Corresponding author: akpenpuun.td@unilorin.edu.ng

\section{INTRODUCTION}

The demand for wood composites has been increasing as timber resources in forests are declining. A large amount of wood consumption could mean a high worldwide deforestation rate that can cause negative impacts on the environment if not reduced. Wood is the material of choice for sustainable and environmentally friendly construction and manufacturing of products. Wood has excellent properties for reuse, which can be realized and implemented through a cascading utilization, introducing intermittent product lives. However, wood waste is still a heavily under-valued resource in Nigeria (Onuegbu 2010; Laleicke 2018; Dumitrascu et al. 2019; Tascioglu et al. 2020).

For the last 80 years, wood has basically been the most used lignocellulosic raw material to produce particleboards. However, due to the high-volume demanded for this renewable raw material, a lack in wood supply is becoming a critical future issue. Therefore, the search for alternative lignocellulosic raw materials that can dampen the pressure on slow-growing forests is essential. In this context, many wastes from lignocellulosic sources could be of strategic matter. The use of alternative raw materials to produce particleboards become an interesting strategy to replace wood and dampen the deforestation that have created environmental issues (Fiorelli et al. 2019). 
Particleboard is a wood-based board product that is manufactured under pressure with or without heat essentially from particles of wood and/or other lingo-cellulosic fibrous materials (wood chips, sawdust and flax shives) and with or without an adhesive. There have been successful developments within the forest products industry in recent times, especially in products generally referred to as particleboards and much of this success can be attributed to the obvious economic advantage of low-cost wood raw material (Nemli et al. 2003).

Aside from wood resources, more than 30 types of agricultural waste have been used as alternative biomass for the production of particleboards, with a trend towards increasing utilization in the future. Sunflower stalks, hazelnut husk, peanut hull, grass clippings, sugar cane bagasse, cereal straws, cotton, maize husk and cab, hemp and jute stalks, rice husks, groundnut shells, bamboo, waste of tea leaves, walnut shell, almond shell, stalks kenaf, and sorghum are some of the byproducts evaluated for the manufacture of particleboards with application in the furniture industry. For the manufacture of these panels, the adhesive is one of the key factors due to their significant technical and economic implications, reaching up to $50 \%$ of the total price. Some studies have revealed that the change in resin content significantly affects the physical and mechanical properties of particleboards (Nemli et al. 2003; Cravo et al. 2019).

Particleboard manufacturing is an inexpensive alternative to solid wood paneling and is a versatile substitute for wood in many applications such as in building construction, decoration, air conditioner duct covering, door panel inserts, wall panels, and floor-ceiling tiles (Rafael et al. 2014; Elbadawi et al. 2015; Akpenpuun et al. 2017). Wood particleboards are manufactured as panels from dry wood particles that have been sprayed or dusted with a binder resin and are bonded together with pressure and heat. Particles for the boards can be made from almost any type of wood, whether whole logs or wood residues such as trimmings and shavings from lumber or plywood manufacturing. Many species are used, although the lower density woods are preferred (Elbadawi et al. 2015).

Particleboard is one of the most widely used wood-based panel composite (such as fiberboard, oriented strand board, hardboard, and plywood) that has applications in the manufacture housing and building components, furniture, flooring, wall and ceiling panels, office dividers, construction and interior decoration (Bardak et al. 2010). As a result, the global production of particleboard has significantly increased in recent years to more than 23 million cubic meters per year. Due to the increase in global consumption, it has a major market share in the wood-based panel industry (Bardak et al. 2010). Currently, particleboard provides industrial users the consistent quality and design flexibility needed for the rapid and efficient production of quality consumer products (Bardak et al. 2010; Elbadawi et al. 2015; Chung and Wang 2019).

Starch can be obtained locally from most carbohydrates that contain high quantity of starch such as corn, rice, and potatoes. However, cassava is the most readily available source of starch. Cassava starch is mostly used as a laundry stiffener in Nigeria. Starch can be used in its native or modified forms (Mohd et al. 2013; Baishya and Maji 2014). Modified starch is obtained by diluting starch with an organic compound such as glutaraldehyde or urea formaldehyde. Glutaraldehyde is used both as a disinfectant and medication in hospitals (Wang et al. 2007; Yang et al. 2015).

Urea formaldehyde has been the major adhesive for particleboard composite manufacturing due to its low cost, short press time, lack of colour in the finished product, excellent adhesion to lignocellulosics and intrinsic cohesion, high reactivity, and water solubility. However, it has high reversibility of the aminomethylene link, which also 
explains the low resistance of urea formaldehyde resins against the influence of water and moisture, especially at higher temperature. This is one of the reasons for its formaldehyde emissions, when hardened and in service (Sari et al. 2010).

Nakanishi et al. (2019) studied two alternative polymeric films based on natural latex and rosin as a waterproofing coating for 3-layer sugarcane-bamboo-based particleboards (3LP) and reported that latex and rosin coatings on the $3 \mathrm{LP}$ did not influence the thermal properties, as well as the mechanical properties of modulus of rupture (MOR) and modulus of elasticity (MOE) under bending. Results showed that all 3LP met the ANSI Standard A208.1-1999 requirements and that latex successfully formed a smooth and continuous film which covered the surface pores of the 3LP, whereas rosin did not form a smooth and continuous, forming only a thin film on the 3LP. However, particleboard durability is prone to degradation when the materials are exposed to environmental conditions such as temperature, ultra-violet (UV) radiation, biological agents and moisture. The degradation can be defined as a biological, chemical, or physical process that results in the loss of productive potential (Nakanishi et al., 2019).

This study evaluated particleboard made from wood chips using native cassava starch or cassava starch modified with glutaraldehyde and urea formaldehyde as binders. The physical and mechanical characteristics of the boards determined were modulus of rupture (MOR), modulus of elasticity (MOE), water absorption rate (WAR), thickness swelling (TS), and scanning electron microscopy (SEM).

\section{EXPERIMENTAL}

\section{Materials}

Wood shavings from red ironwood (Lophira alata), urea formaldehyde, glutaraldehyde, and cassava starch (the binder) were obtained. The wood shavings were screened using 0.85- and 1.7-mm sieves and were air-dried to reduce the moisture content to approximately 3 to $5 \%$. The particles retained on the $0.85-\mathrm{mm}$ or $1.7-\mathrm{mm}$ sieves were used alternatively for the particleboard preparation. The starch was initially dissolved in warm water $\left(30^{\circ} \mathrm{C}\right)$ and then in boiling water $\left(100^{\circ} \mathrm{C}\right)$ to form a colloidal solution. The urea formaldehyde and glutaraldehyde were used to modify the starch. The moulds were made from wood and rectangular in cross-section $(610 \times 300 \mathrm{~mm})$. The particleboards were made from each type of the material by applying $3.5 \mathrm{~N} / \mathrm{mm}^{2}$ pressure at $37^{\circ} \mathrm{C}$ (room temperature) press temperature.

\section{Particleboard Production}

Test samples were prepared based on EN standards (EN 319, 1993) and conditioned for about a week at $65 \%$ relative humidity and at room temperature of $37{ }^{\circ} \mathrm{C}$ prior to tests. Modulus of rupture (MOR), modulus of elasticity (MOE), water absorption rate (WAR), thickness swelling (TS), and scanning electron microscopy (SEM) were determined using three specimens from each panel. Table 1 shows the mix design for each of the particleboard sample, while Fig. 1 shows one of the manufactured boards ([P1-D (1.5)MCS]) (Fiorelli et al. 2019).

\section{Water Absorption and Thickness Swelling Test}

Water absorption and thickness swelling tests were carried out in accordance with ASTM D 1037-23 (2012) using $70 \times 70 \times 35 \mathrm{~mm}^{3}$ sample size. The difference in the 
weights of the oven dried and wet samples after $2 \mathrm{~h}$ and $24 \mathrm{~h}$ were recorded. Water absorption and thickness swelling were determined using Eq. 1,

$$
\text { Water absorption }=[(w w-d w) /(d w)] 100 \%
$$

where $w w$ is wet weight $(\mathrm{kg})$ and $d w$ is dry weight $(\mathrm{kg})$.

Table 1. Particleboard Mix Design

\begin{tabular}{|c|c|c|c|c|}
\hline $\begin{array}{c}\text { Sample } \\
\text { name }\end{array}$ & Sample & $\begin{array}{c}\text { Particle Size } \\
(\mathrm{mm})\end{array}$ & $\begin{array}{c}\text { Binder/ } \\
\text { Dosage }(\mathrm{mL})\end{array}$ & $\begin{array}{l}\text { Additive/ } \\
\text { Volume }\end{array}$ \\
\hline $\mathrm{R}$ & [P1-D (1.5)-MCS] & 0.85 & $\begin{array}{c}\text { modified cassava } \\
\text { starch } \\
\text { (MCS) } / 1.0\end{array}$ & $\begin{array}{l}\text { glutaraldehyde } \\
\text { solution } / 500 \mathrm{~mL}\end{array}$ \\
\hline I & [P1-D (1.5)-SA] & 0.85 & $\begin{array}{c}\text { binder starch alone } \\
(\mathrm{SA}) / 1.2\end{array}$ & $\begin{array}{l}\text { urea formaldehyde } \\
\qquad / 300 \mathrm{~mL}\end{array}$ \\
\hline D & [P1-D (2.5)-MCS] & 0.85 & MCS/2.4 & $\begin{array}{l}\text { glutaraldehyde/ } \\
100 \mathrm{~mL}\end{array}$ \\
\hline W & [P1-D (2.5)-SA] & 0.85 & $\mathrm{MCS} / 2.0$ & $\begin{array}{l}\text { urea formaldehyde/ } \\
500 \mathrm{~mL}\end{array}$ \\
\hline A & [P2-D (1.5)-MCS] & 1.70 & $\begin{array}{c}\text { modified cassava } \\
\text { starch MCS } / 2.0\end{array}$ & $\begin{array}{c}\text { glutaraldehyde / } 500 \\
\mathrm{~mL}\end{array}$ \\
\hline $\mathrm{N}$ & [P2-D (1.5)-SA] & 1.70 & SA/1.2 & $\begin{array}{c}\text { urea } \\
\text { formaldehyde } / 300 \mathrm{~mL}\end{array}$ \\
\hline G & [P2-D (2.5)-MCS] & 1.70 & $\mathrm{MCS} / 2.40$ & $\begin{array}{c}\text { glutaraldehyde/ } \\
100 \mathrm{~mL}\end{array}$ \\
\hline B & [P2-D (2.5)-SA] & 1.70 & $\mathrm{SA} / 2.0$ & $\begin{array}{l}\text { urea formaldehyde = } \\
500 \mathrm{~mL}\end{array}$ \\
\hline
\end{tabular}

Note: The weight of red Ironwood (Lophira alata) chips in all samples was $1 \mathrm{~kg}$.

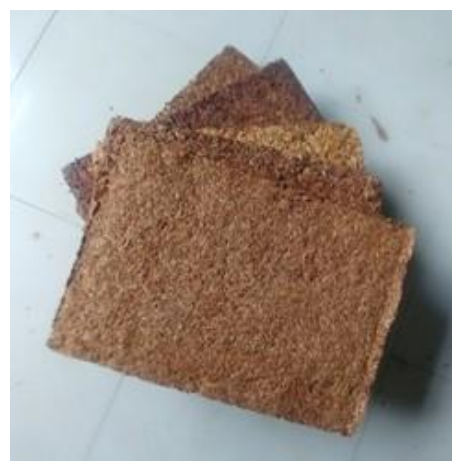

Fig. 1. Particleboards

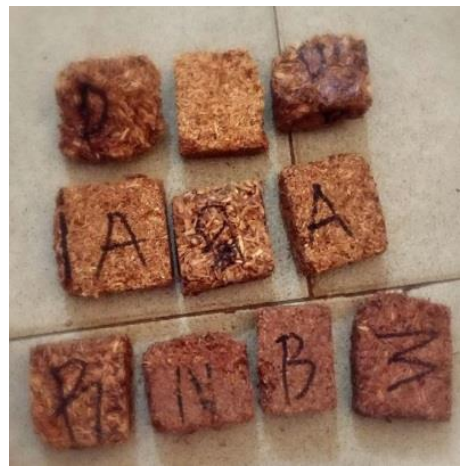

Fig. 2. Samples for water absorption and thickness swelling tests

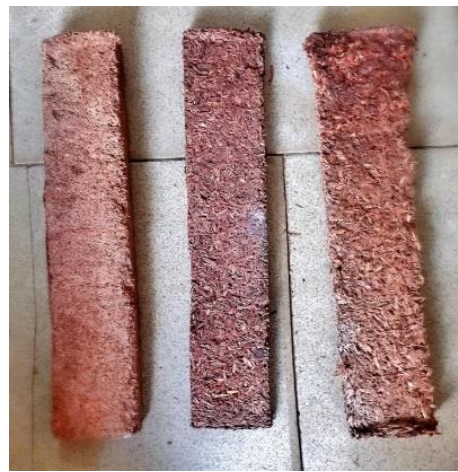

Fig. 3. Samples for the flexural tests

\section{Flexural Strength Test}

The flexural strengths of the specimens were determined in accordance with ASTM D 1037-33 (2012). The modulus of elasticity (MOE) and modulus of rupture (MOR) were calculated from load-deflection curves of a universal testing machine (Testometric M50050AT, Rochdale, UK) using Eqs. 2 and 3, respectively,

$$
\begin{aligned}
& \mathrm{MOR}=3 P L / 2 b h^{2} \\
& \mathrm{MOE}=P L^{3} / 4 b h^{3} Y
\end{aligned}
$$


where $P$ is maximum load $(\mathrm{N}), L$ is span $(\mathrm{m}), h$ is thickness $(\mathrm{mm}), b$ is width $(\mathrm{mm})$ and $Y$ is deflection $(\mathrm{mm})$.

\section{Scanning Electron Microscopy}

The-JEOL JSM-7600F scanning electron microscope (Sao Paulo, Brazil) was used to observe the samples. The dimensions of samples for the SEM test was $20 \times 2.5 \times 10.5$ $\mathrm{mm}$ and was carried out on type R (modified cassava starch) and type B (starch alone). The SEM images were taken at three different magnification of 10000x, 11000x, and 12000x or 6000x, 8000x, and 10000x. The test was determined in accordance with ASTM E98604 (2017).

\section{Statistical Analysis}

Data for each test were statistically analyzed. Analyze of variance (ANOVA) was used to test for significant difference between factors and levels. When the ANOVA indicated a significant difference among factors and levels, a multiple comparison of the means was done employing a Tukey HSD test to identify which pairs of factors were significantly different from each other.

\section{RESULTS AND DISCUSSION}

\section{Water Absorption, WA}

The result of water absorption is presented in Table 2. The average water absorption of the samples ranged from 32.7 to $140.7 \%$ for $2 \mathrm{~h}$ immersion and ranged from 33.8 to $168.9 \%$ for $24 \mathrm{~h}$ immersion. The result in Table 2 shows that sample I [P1-D (1.5) - SA] had the best water absorptive quality because it had the lowest value for both $2 \mathrm{~h}$ and $24 \mathrm{~h}$ water absorption percentage.

Table 2. Water Absorption RATE

\begin{tabular}{|c|c|c|c|c|c|}
\hline \multirow[t]{2}{*}{ Sample name } & \multirow[t]{2}{*}{ Duration } & $\mathbf{1}^{\text {st }}$ Reading & $2^{\text {nd }}$ Reading & $3^{\text {rd }}$ Reading & Average \\
\hline & & \multicolumn{4}{|c|}{$\%$} \\
\hline \multirow{2}{*}{$\mathrm{R}$} & $2 \mathrm{~h}$ & 65.71 & 83.17 & 79.72 & 76.2 \\
\hline & $24 \mathrm{~h}$ & 70.82 & 86.25 & 86.84 & 81.30 \\
\hline \multirow{2}{*}{ I } & $2 \mathrm{~h}$ & 32.19 & 37.59 & 28.19 & 32.66 \\
\hline & $24 \mathrm{~h}$ & 34.35 & 38.29 & 28.87 & 33.84 \\
\hline \multirow{2}{*}{ D } & $2 \mathrm{~h}$ & 82.18 & 93.85 & 102.50 & 92.84 \\
\hline & $24 \mathrm{~h}$ & 87.28 & 95.85 & 118.50 & 100.54 \\
\hline \multirow{2}{*}{ W } & $2 \mathrm{~h}$ & 108.72 & 100.21 & 120.76 & 109.90 \\
\hline & $24 \mathrm{~h}$ & 110.18 & 106.93 & 128.63 & 115.25 \\
\hline \multirow{2}{*}{ A } & $2 \mathrm{~h}$ & 43.90 & 38.74 & 32.21 & 38.28 \\
\hline & $24 \mathrm{~h}$ & 55.82 & 54.00 & 48.96 & 52.93 \\
\hline \multirow{2}{*}{$\mathrm{N}$} & $2 \mathrm{~h}$ & 85.80 & 91.13 & 80.04 & 85.66 \\
\hline & $24 \mathrm{~h}$ & 110.18 & 106.93 & 95.06 & 104.06 \\
\hline \multirow{2}{*}{ G } & $2 \mathrm{~h}$ & 55.21 & 63.12 & 52.11 & 56.81 \\
\hline & $24 \mathrm{~h}$ & 78.39 & 88.45 & 79.55 & 82.13 \\
\hline \multirow{2}{*}{ B } & $2 \mathrm{~h}$ & 139.82 & 132.11 & 150.30 & 140.74 \\
\hline & $24 \mathrm{~h}$ & 173.58 & 169.79 & 163.20 & 168.86 \\
\hline
\end{tabular}

$\mathrm{R}=$ [P1-D (1.5)-MCS]; I = [P1-D (1.5)-SA]; D = [P1-D (2.5)-MCS]; W = [P1-D (2.5)-SA]; A = [P2-D (1.5)-MCS]; N = [P2-D (1.5)-SA]; G = [P2-D (2.5)-MCS]; B = [P2-D (2.5)-SA] 
Table 2 shows that the samples made with the big wood chips $(\mathrm{P} 1=0.85 \mathrm{~mm})$ absorbed water faster than the samples from the smaller wood chip particles $(\mathrm{P} 2=1.7 \mathrm{~mm})$ after the $2 \mathrm{~h}$ water absorption test, but the samples from P2 absorbed more water than the samples made from P1 after $24 \mathrm{~h}$. The samples from P2 were slower at absorbing water, but eventually absorbed more water than the samples from P1. Guler and Buyuksari (2011) reported a water absorption range of 67.8 to $94.9 \%$ in particleboards made using peanut hulls and urea formaldehyde that were cured for $24 \mathrm{~h}$.

The samples fabricated using modified cassava starch (MCS) had a lower water absorption rate than the samples produced using starch alone (SA). Table 2 shows that the particleboards with D1.5 of binder absorbed less water, but they absorbed water faster than the particleboards with D2.5.

The lower value of water absorption for the samples produced with modified cassava starch indicated that the glutaraldehyde treatment reduced the water absorption of the particleboards. The water absorption data was subjected to one-way single factor analysis of variance, and the result showed that water absorption after 2 and $24 \mathrm{~h}$ differed significantly between the board samples with the corresponding F-statistics, Fcritical, and p-values were 25.96, 2.42 and p $<0.01$, respectively, while after $24 \mathrm{~h}$ the corresponding Fstatistics, Fcritical, and p-values were 127.09, 2.42 and $\mathrm{p}<0.01$, respectively. This is similar to previous results showing that water absorption affects the strength between the board structure and fiber interface, which in turn influences dimensional stability and the mechanical and physical properties Chung and Wang (2019). Table 3 shows the ANOVA result of panels immersed in water for $2 \mathrm{~h}$ against panels immersed in water for $24 \mathrm{~h}$. The result shows that the ANOVA for samples R, I, D and W was statistically insignificant, while for samples A, N, G and B the comparison were statistically significant.

Table 3. ANOVA of 2 and $24 \mathrm{~h}$ Immersion

\begin{tabular}{|c|c|c|c|c|}
\hline Combination & F & P-value & F crit & Inference \\
\hline R2h/R24h & 0.93 & 0.37 & 5.99 & Insignificant \\
\hline I2h/I24h & 0.19 & 0.68 & 5.99 & Insignificant \\
\hline D2h/D24h & 0.98 & 0.36 & 5.99 & Insignificant \\
\hline W2h/W24h & 0.71 & 0.43 & 5.99 & Insignificant \\
\hline A2h/A24h & 27.41 & 0.00 & 5.99 & Significant \\
\hline N2h/N24h & 14.56 & 0.01 & 5.99 & Significant \\
\hline G2h/G24h & 61.51 & 0.00 & 5.99 & Significant \\
\hline B2h/B24h & 42.75 & 0.00 & 5.99 & Significant \\
\hline
\end{tabular}

\section{Thickness Swelling, TS}

Table 4 shows the thickness swelling test result after 2 and $24 \mathrm{~h}$. The thickness swelling increased with the immersion time until equilibrium conditions were reached. The thickness swelling value ranged from 1.8 to $59.4 \%$ for $2 \mathrm{~h}$ immersion and ranged from 2.6 to $67.9 \%$ for the $24 \mathrm{~h}$ immersion. Tables 3 shows that sample I [P1-D (1.5) - SA] had the lowest value for thickness swelling percentage, and the sample with the highest thickness swelling percentage was sample D[P1-D(2.5)-MCS].

The results in Table 3 show that the samples fabricated from the larger size of wood chips particle $(\mathrm{P} 1=0.85 \mathrm{~mm})$ had higher values of thickness swelling at both $2 \mathrm{~h}$ and $24 \mathrm{~h}$ than the samples made from smaller particles $(\mathrm{P} 2=1.7 \mathrm{~mm})$. This result corresponds with 
(Mohd et al. 2013), who reported that particle size had an effect on thickness swelling of particleboard made from $1.9 \mathrm{~mm}$ wood particles.

The samples produced with D2.5 dosage of binder samples swelled in thickness more than D1.5 dosage of binder samples. The samples produced using $1.70 \mathrm{~mm}$ particle size and modified cassava starch (MCS) as binder had high thickness swelling value than the samples produced using $0.85 \mathrm{~mm}$ particle size and starch alone (SA) as a binder. This may be due to the large number of fine particles in the face layers, which makes the face layers so compact and impermeable to moisture. This is similar to the report of Amini et al. (2016), where $2 \%$ replacement of modified starch with urea formaldehyde showed increased dimensional stability, while Guler and Buyuksari (2011) and Kalaycioglu and Nemli (2006) reported thickness swelling of 12.3 to $25.7 \%$ and 10.2 to $27.5 \%$ for $2 \mathrm{~h}$ immersion of kenaf panels ranging.

The likely reason for high TS and WA values is the presence of vegetal particle polar groups, which attract water molecules through hydrogen bonding. Therefore, this phenomenon leads to a moisture build-up in the fiber cell wall (fiber swelling) and also in the fiber-adhesive interface, resulting in changes in the dimensions of the specimens (Nakanishi et al. 2019).

Table 4. Thickness Swelling

\begin{tabular}{|c|c|c|c|c|c|}
\hline \multirow[t]{2}{*}{ Sample } & \multirow[t]{2}{*}{ Duration } & $1^{\text {st }}$ Reading & $2^{\text {nd }}$ Reading & $3^{\text {rd }}$ Reading & Average \\
\hline & & \multicolumn{4}{|c|}{ (\%) } \\
\hline \multirow[t]{2}{*}{$\mathrm{R}$} & After $2 \mathrm{~h}$ & 7.67 & 5.20 & 14.1 & 8.99 \\
\hline & After $24 \mathrm{~h}$ & 18.53 & 9.96 & 18.18 & 15.56 \\
\hline \multirow[t]{2}{*}{$\mathrm{I}$} & After $2 \mathrm{~h}$ & 0.72 & 3.70 & 1.05 & 1.82 \\
\hline & After $24 \mathrm{~h}$ & 1.96 & 4.12 & 1.76 & 2.61 \\
\hline \multirow[t]{2}{*}{ D } & After $2 \mathrm{~h}$ & 57.33 & 60.46 & 60.31 & 59.37 \\
\hline & After $24 \mathrm{~h}$ & 64.24 & 71.35 & 68.15 & 67.91 \\
\hline \multirow[t]{2}{*}{ W } & After $2 \mathrm{~h}$ & 19.22 & 22.46 & 30.81 & 24.16 \\
\hline & After $24 \mathrm{~h}$ & 38.73 & 33.51 & 34.35 & 35.53 \\
\hline \multirow[t]{2}{*}{ A } & After $2 \mathrm{~h}$ & 2.62 & 4.05 & 2.34 & 3.00 \\
\hline & After $24 \mathrm{~h}$ & 6.09 & 5.40 & 2.91 & 4.8 \\
\hline \multirow[t]{2}{*}{$\mathrm{N}$} & After $2 \mathrm{~h}$ & 7.19 & 11.53 & 18.23 & 12.32 \\
\hline & After $24 \mathrm{~h}$ & 8.81 & 17.66 & 19.69 & 15.39 \\
\hline \multirow[t]{2}{*}{ G } & After $2 \mathrm{~h}$ & 15.88 & 4.09 & 20.78 & 13.58 \\
\hline & After $24 \mathrm{~h}$ & 17.57 & 24.60 & 27.07 & 23.08 \\
\hline \multirow[t]{2}{*}{ B } & After $2 \mathrm{~h}$ & 4.29 & 8.53 & 12.32 & 8.38 \\
\hline & After $24 \mathrm{~h}$ & 13.29 & 11.80 & 12.63 & 12.57 \\
\hline
\end{tabular}

$\mathrm{R}=$ [P1-D (1.5)-MCS]; I = [P1-D (1.5)-SA]; D = [P1-D (2.5)-MCS]; W = [P1-D (2.5)-SA]; A = [P2-D (1.5)-MCS]; N = [P2-D (1.5)-SA]; G = [P2-D (2.5)-MCS]; B = [P2-D (2.5)-SA]

The thickness swelling data was subjected to one-way single factor analysis of variance, and the result showed that thickness swelling of board samples after 2 and $24 \mathrm{~h}$ differed significantly with the corresponding Fstatitstics, Fcritical, and p-values of 90.94, 2.42 , and $\mathrm{p}<0.01$ and 201.29, 2.42 and $\mathrm{p}<0.01$, respectively. Presented in Table 5 is the ANOVA of 2 and $24 \mathrm{~h}$ immersion of samples in water. The ANOVA shows that samples I, A, N and $\mathrm{G}$ were statistically insignificant, while R, D, W and B were statistically significant. 
Table 5. ANOVA of 2 and $24 \mathrm{~h}$ Immersion

\begin{tabular}{|l|c|c|c|c|}
\hline Combination & $F$ & $P$-value & $F$ crit & Inference \\
\hline R2h/R24h & 5.80 & 0.05 & 5.99 & Significant \\
\hline I2h/I24h & 0.85 & 0.39 & 5.99 & Insignificant \\
\hline D2h/D24h & 27.73 & 0.00 & 5.99 & Significant \\
\hline W2h/W24h & 17.78 & 0.01 & 5.99 & Significant \\
\hline A2h/A24h & 5.33 & 0.06 & 5.99 & Insignificant \\
\hline N2h/N24h & 0.88 & 0.38 & 5.99 & Insignificant \\
\hline G2h/G24h & 5.53 & 0.06 & 5.99 & Insignificant \\
\hline B2h/B24h & 6.32 & 0.05 & 5.99 & Significant \\
\hline
\end{tabular}

The p-value corresponding to the F-statistic of one-way ANOVA was statistically significant at $\mathrm{p}=0.01$ or $\mathrm{p}=0.05$ in the water absorption rate and thickness swelling analysis, which strongly suggests that one or more pairs of treatments (RIDWANGB) were significantly different.

The Tukey-Kramer HSD Qstatistic was obtained in the Studentized Range distribution using degrees of freedom of 8 and 24 for the error term at the significance levels $\alpha=0.01$ and 0.05 ( $\mathrm{p}$-values). The critical values for $\mathrm{Q}$, for $\alpha$ of 0.01 and 0.05 , as $\mathrm{Q}^{\alpha=0.01, \mathrm{k}=8, \nu=24}=5.68$ and $\mathrm{Q}^{\alpha=0.05, \mathrm{k}=8, \nu=24}=4.68$, respectively. The Tukey HSD test results presented in Tables 3 and 4 show the pairs of particleboard samples whose water absorption rate and thickness swelling were statistically significantly different, while Tables 6 and 7 show the pairs of particleboard samples whose water absorption rate and thickness swelling were statistically insignificantly different.

Table 6. Tukey HSD Test of Water Absorption Rate Statistical Significance

\begin{tabular}{|c|c|c|c|c|}
\hline S/No. & $\begin{array}{c}\text { Treatments } \\
\text { pair }\end{array}$ & $\begin{array}{c}\text { Tukey HSD } \\
\text { Q statistic }\end{array}$ & $\begin{array}{c}\text { Tukey HSD } \\
\text { p-value }\end{array}$ & $\begin{array}{c}\text { Tukey HSD } \\
\text { inference }\end{array}$ \\
\hline 1 & R vs I & 5.35 & 0.02 & ${ }^{*} p<0.05$ \\
\hline 2 & R vs N & 6.65 & 0.00 & ${ }^{* *} p<0.01$ \\
\hline 3 & R vs B & 7.93 & 0.00 & ${ }^{* *} p<0.01$ \\
\hline 4 & I vs D & 7.40 & 0.00 & ${ }^{* *} p<0.01$ \\
\hline 5 & I vs W & 9.50 & 0.00 & ${ }^{* *} p<0.01$ \\
\hline 6 & I vs B & 13.29 & 0.00 & ${ }^{* *} p<0.01$ \\
\hline 7 & D vs R & 6.71 & 0.00 & ${ }^{* *} p<0.01$ \\
\hline 8 & D vs N & 8.70 & 0.00 & ${ }^{* *} p<0.01$ \\
\hline 9 & D vs B & 5.89 & 0.01 & ${ }^{* *} p<0.01$ \\
\hline 10 & W vs R & 8.81 & 0.00 & ${ }^{* *} p<0.01$ \\
\hline 11 & W vs N & 10.80 & 0.00 & ${ }^{* *} p<0.01$ \\
\hline 12 & W vs G & 6.53 & 0.00 & ${ }^{* *} p<0.01$ \\
\hline 13 & A vs B & 12.60 & 0.00 & ${ }^{* *} p<0.01$ \\
\hline 14 & N vs B & 14.59 & 0.00 & ${ }^{* *} p<0.01$ \\
\hline 15 & G vs B & 10.32 & 0.00 & ${ }^{* *} p<0.01$ \\
\hline
\end{tabular}


Table 7. Tukey HSD test of Thickness Swelling Statistical Significance

\begin{tabular}{|c|c|c|c|c|}
\hline S/No. & $\begin{array}{l}\text { Treatments } \\
\text { pair }\end{array}$ & $\begin{array}{c}\text { Tukey HSD Q } \\
\text { statistic }\end{array}$ & $\begin{array}{l}\text { Tukey HSD } \\
\text { p-value }\end{array}$ & $\begin{array}{c}\text { Tukey HSD } \\
\text { inference }\end{array}$ \\
\hline 1 & R vs I & 13.05 & 0.00 & ${ }^{* *} p<0.01$ \\
\hline 2 & $R$ vs $D$ & 5.29 & 0.02 & ${ }^{*} p<0.05$ \\
\hline 3 & $R$ vs $W$ & 9.33 & 0.00 & ${ }^{* *} p<0.01$ \\
\hline 4 & $R$ vs $A$ & 7.80 & 0.00 & ${ }^{* *} p<0.01$ \\
\hline 5 & R vs $N$ & 6.26 & 0.00 & ${ }^{* *} p<0.01$ \\
\hline 6 & $R$ vs $B$ & 24.08 & 0.00 & ${ }^{* *} p<0.01$ \\
\hline 7 & I vs D & 18.34 & 0.00 & ${ }^{* *} p<0.01$ \\
\hline 8 & I vs W & 22.38 & 0.00 & ${ }^{* *} p<0.01$ \\
\hline 9 & I vs $A$ & 5.24 & 0.02 & ${ }^{*} p<0.05$ \\
\hline 10 & I vs N & 19.31 & 0.00 & ${ }^{* *} p<0.01$ \\
\hline 11 & I vs G & 13.28 & 0.00 & ${ }^{* *} p<0.01$ \\
\hline 12 & I vs B & 37.12 & 0.00 & ${ }^{* *} p<0.01$ \\
\hline 13 & $D$ vs $A$ & 13.09 & 0.00 & ${ }^{* *} p<0.01$ \\
\hline 14 & $D$ vs $G$ & 5.06 & 0.03 & ${ }^{*} p<0.05$ \\
\hline 15 & D vs $B$ & 18.78 & 0.00 & ${ }^{* *} p<0.01$ \\
\hline 16 & $W$ vs $A$ & 17.13 & 0.00 & ${ }^{* *} p<0.01$ \\
\hline 17 & $W$ vs $G$ & 9.10 & 0.00 & ${ }^{* *} p<0.01$ \\
\hline 18 & $W$ vs $B$ & 14.74 & 0.00 & ${ }^{* *} p<0.01$ \\
\hline 19 & $A$ vs $N$ & 14.06 & 0.00 & ${ }^{* *} p<0.01$ \\
\hline 20 & $A$ vs $G$ & 8.03 & 0.00 & ${ }^{* *} p<0.01$ \\
\hline 21 & $A$ vs $B$ & 31.88 & 0.00 & ${ }^{* *} p<0.01$ \\
\hline 22 & $N$ vs $G$ & 6.03 & 0.01 & ${ }^{* *} p<0.01$ \\
\hline 23 & $\mathrm{~N}$ vs $\mathrm{B}$ & 17.82 & 0.00 & ${ }^{* *} p<0.01$ \\
\hline 24 & $G$ vs $B$ & 23.84 & 0.00 & ${ }^{* *} p<0.01$ \\
\hline
\end{tabular}

Table 8. Tukey HSD Test of Water Absorption Rate Statistically Insignificant

\begin{tabular}{|c|l|c|c|l|}
\hline S/No. & $\begin{array}{c}\text { Treatments } \\
\text { pair }\end{array}$ & $\begin{array}{c}\text { Tukey HSD } \\
\text { Q statistic }\end{array}$ & $\begin{array}{c}\text { Tukey HSD } \\
\text { p-value }\end{array}$ & $\begin{array}{l}\text { Tukey HSD } \\
\text { inference }\end{array}$ \\
\hline 1 & R vs D & 2.05 & 0.80 & insignificant \\
\hline 2 & R vs W & 4.14 & 0.11 & insignificant \\
\hline 3 & R vs R & 4.66 & 0.05 & insignificant \\
\hline 4 & R vs G & 2.39 & 0.67 & insignificant \\
\hline 5 & I vs R & 0.69 & 0.90 & insignificant \\
\hline 6 & I vs N & 1.30 & 0.90 & insignificant \\
\hline 7 & I vs G & 2.97 & 0.45 & insignificant \\
\hline 8 & D vs W & 2.10 & 0.78 & insignificant \\
\hline 9 & D vs G & 4.43 & 0.07 & insignificant \\
\hline 10 & W vs B & 3.79 & 0.18 & insignificant \\
\hline 11 & R vs N & 1.99 & 0.83 & insignificant \\
\hline 12 & R vs G & 2.28 & 0.71 & insignificant \\
\hline 13 & $\mathrm{~N}$ vs G & 4.27 & 0.09 & insignificant \\
\hline
\end{tabular}


Table 9. Tukey HSD test of Thickness Swelling Statistically Insignificant

\begin{tabular}{|c|l|r|r|r|}
\hline S/No. & $\begin{array}{c}\text { Treatments } \\
\text { pair }\end{array}$ & $\begin{array}{c}\text { Tukey HSD } \\
\text { Q statistic }\end{array}$ & $\begin{array}{c}\text { Tukey HSD } \\
\text { p-value }\end{array}$ & $\begin{array}{c}\text { Tukey HSD } \\
\text { inference }\end{array}$ \\
\hline 1 & R vs G & 0.23 & 0.90 & insignificant \\
\hline 2 & D vs W & 4.04 & 0.13 & insignificant \\
\hline 3 & D vs N & 0.97 & 0.90 & insignificant \\
\hline 4 & W vs N & 3.07 & 0.40 & insignificant \\
\hline
\end{tabular}

\section{Flexural Tests}

The mechanical properties of five specimens of each composition and the average values are presented in Table 10. The particleboards produced using modified cassava starch gave the highest value of modulus of elasticity (MOE), ranging from 5.9 to 32.3 $\mathrm{N} / \mathrm{mm}^{2}$. The MOR of the particleboards was in the range of 0.055 to $0.342 \mathrm{~N} / \mathrm{mm}^{2}$, indicating the highest value of $0.34 \mathrm{~N} / \mathrm{mm}^{2}$ for the sample R [P1-D (1.5)-MCS]. P1-D (1.5)/1.7 mm size wood chips and P2- D (2.5)/0.85 mm wood chips board samples had the highest MOR. de Melo et al. (2014) reported a similar MOE range of 5.2 to $34.3 \mathrm{~N} / \mathrm{mm}^{2}$ and MOR in the range of 0.09 to $0.85 \mathrm{~N} / \mathrm{mm}^{2}$ using modified cassava starch for the production of particleboards from Ailanthus wood. Kalaycioglu and Nemli (2006) reported an average modulus of rupture ranged from 12.7 to $16.9 \mathrm{~N} / \mathrm{mm}^{2}$ of composite particleboard from kenaf (Hibiscus cannabinus L.) stalks.

Table 10. Mechanical Properties of Boards

\begin{tabular}{|c|c|c|c|c|c|}
\hline \multirow{2}{*}{ Sample } & \multirow{2}{*}{ Test } & $1^{\text {st }}$ Reading & $2^{\text {nd }}$ Reading & $3^{\text {rd }}$ Reading & Average \\
\hline & & \multicolumn{4}{|c|}{$\mathrm{MPa}$} \\
\hline \multirow{2}{*}{$\mathrm{R}$} & MOE & 25.59 & 10.99 & 25.29 & 20.62 \\
\hline & MOR & 0.38 & 0.32 & 0.33 & 0.34 \\
\hline \multirow{2}{*}{ I } & MOE & 11.16 & 12.03 & 12.30 & 11.83 \\
\hline & MOR & 0.24 & 0.24 & 0.28 & 0.25 \\
\hline \multirow{2}{*}{ D } & MOE & 10.12 & 4.34 & 3.26 & 5.91 \\
\hline & MOR & 0.21 & 0.12 & 0.08 & 0.14 \\
\hline \multirow{2}{*}{ W } & MOE & 1.78 & 2.13 & 2.28 & 2.06 \\
\hline & MOR & 0.10 & 0.11 & 0.12 & 0.11 \\
\hline \multirow{2}{*}{ A } & MOE & 8.37 & 17.04 & 31.16 & 18.86 \\
\hline & MOR & 0.08 & 0.244 & 0.274 & 0.20 \\
\hline \multirow{2}{*}{$\mathrm{N}$} & MOE & 1.77 & 1.85 & 0.761 & 1.46 \\
\hline & MOR & 0.06 & 0.06 & 0.05 & 0.06 \\
\hline \multirow[b]{2}{*}{ G } & MOE & 29.95 & 23.75 & 43.26 & 32.32 \\
\hline & MOR & 0.32 & 0.35 & 0.29 & 0.32 \\
\hline \multirow{2}{*}{ B } & MOE & 2.38 & 4.93 & 3.31 & 3.54 \\
\hline & MOR & 0.08 & 0.14 & 0.4 & 0.12 \\
\hline
\end{tabular}

The minimum requirements of the modulus of rupture are 11.5 and $13 \mathrm{~N} / \mathrm{mm}^{2}$ for general purpose, and interior fitments (EN 312-2, 1996). Nemli et al. (2003) reported a MOR ranged from 7.3 to $13.3 \mathrm{~N} / \mathrm{mm}^{2}$. The MOR requirements of $11.5 \mathrm{~N} / \mathrm{mm}^{2}$ for general purpose boards by EN 312-2 (1996). Chung and Wang (2019) reported the lowest MOE and MOR of $1.9 \times 10^{3} \mathrm{~N} / \mathrm{mm}^{2}$ and $15.0 \mathrm{~N} / \mathrm{mm}^{2}$, respectively, for bamboo and waste 
particleboards, while Dumitrascu et al. (2019) reported maximum MOR and MOE of 78 and $6.35 \times 10^{3} \mathrm{~N} / \mathrm{mm}^{2}$, respectively in panels manufactured from birch wood. Bardak et al. (2010), however, reported $\mathrm{MOE}$ in the range of 1418.6 to $2248.3 \mathrm{~N} / \mathrm{mm}^{2}$ of particleboard manufactured from waste sanding dusts, while the MOE requirement for furniture manufacturing is $1600 \mathrm{~N} / \mathrm{mm}^{2}$. This result shows that a smaller dosage of the binder is required when manufacturing boards from large wood chips than when using small wood chips.

All particleboards produced with the modified cassava starch have much higher MOE and MOR than the boards produced with starch alone as a binder. Glutaraldehyde modification had a positive effect on the MOR and MOE of the particleboard. The higher mechanical properties of the samples due to chemical modification was an indication of improved interaction and stress transfer between the individual particles of the board (Zhang et al. 2014; Elbadawi et al. 2016). Table 5 shows the analysis of variance performed on the MOE and MOR data from samples of each board formulation. The ANOVA shows that MOE and MOR varied significantly between samples.

In addition, the MOR and MOE values of the panels were close to those reported in the literature for sugarcane-based particleboards (around 6.32 MPa for MOR and 1275 $\mathrm{MPa}$ for MOE) [16] and low-density pine wood particleboards (8.70 MPa for MOR and $1266 \mathrm{MPa}$ for MOE) (Fiorelli et al. 2019).

Table 11. MOE and MOR Analysis of Variance

\begin{tabular}{|c|c|c|c|}
\hline & F-value & P-value & F critical \\
\hline MOE & 9.21 & 0.00 & 2.66 \\
\hline MOR & 5.15 & 0.00 & 2.66 \\
\hline
\end{tabular}

$\mathrm{df}_{1}=7, \mathrm{df}_{2}=16$

The particleboard formulation G [P2-D (2.5)-MCS] recorded average MOR and MOE values of to $0.32 \mathrm{~N} / \mathrm{mm}^{2}$ and $32.3 \mathrm{~N} / \mathrm{mm}^{2}$, respectively, the highest values recorded in comparison to other formulations. Raju et al. (2012) reported a maximum MOR and MOE of $40.6 \mathrm{~N} / \mathrm{mm}^{2}$ and $8.20 \times 10^{3} \mathrm{~N} / \mathrm{mm}^{2}$ of particles boards manufactured using modified starch, while Guler and Buyuksari (2011) reported that the MOR and MOE of boards manufactured using urea formaldehyde were in the range of 2.90 to $12.14 \mathrm{~N} / \mathrm{mm}^{2}$ and 20.4 to $57.2 \mathrm{~N} / \mathrm{mm}^{2}$, respectively.

As mentioned before, the lower mechanical properties (MOR and MOE) can be explained by the degradation of the starch and fibers due to the water, which acts as an oxidation and fiber swelling accelerator. However, there are two factors to be considered regarding accelerated aging tests of particleboards, which together with water, generate a degrading effect on the material: (1) Photooxidation caused by solar irradiation, damaging the polymer molecular and chemical structures of the fiber, (2) temperature, causing the thermal oxidation due to the free radicals, causing the dissociation of the polymer chains (Nakanishi et al. 2019).

\section{SEM Analysis}

The results from the scanning electron microscope are mainly in the form of visual images, supported by quantitative analysis of data on micro-checks and voids. The SEM images in Figs. 4 to 7 show well defined, plate-like, near rectangular crystal formations in 
sample B at 6000x magnification. Also, the crystal formations in sample B at 10000x magnification are circular in appearance and closely packed together. The developed and well-defined crystals formations show that there is a successful high strength bond formation between the modified cassava starch and wood chips at 1.5 dosages of the binder.

The EDS analysis result for sample B shows that the major elements in the composition are calcium, aluminum, carbon, sulphur, silicon and potassium, while the minor components are magnesium, iron, oxygen, and sodium (Fig. 5).

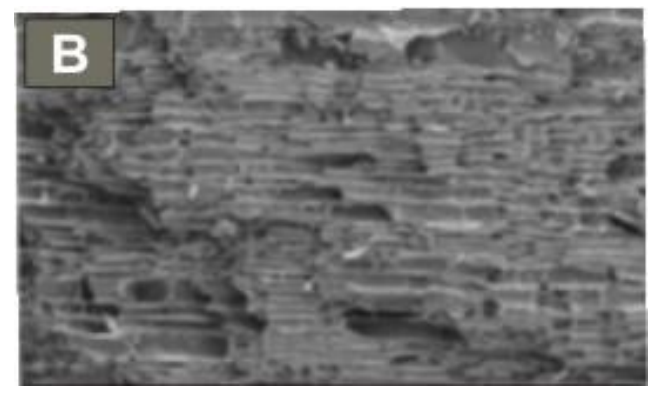

Fig. 4. SEM images of sample $B$ at magnification $\times 6000$

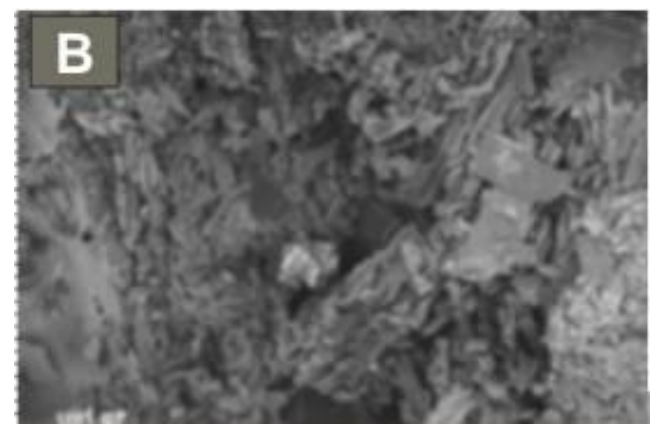

Fig. 5. SEM images of sample $B$ at magnification $\times 8000$

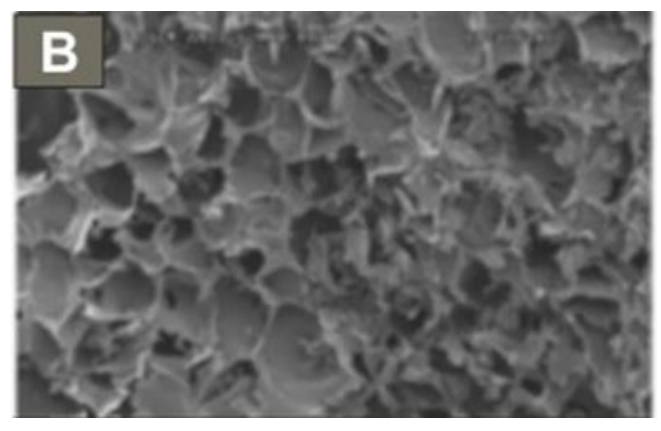

Fig. 6. SEM images of sample $B$ at magnification $\times 10000$

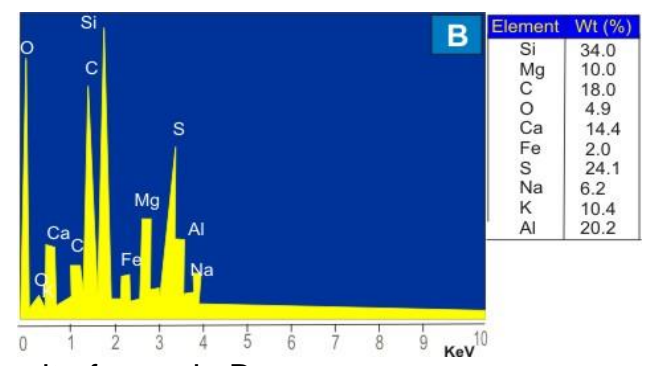

Fig. 7. The EDS analysis result of sample $B$ 
The SEM images for sample $\mathrm{R}$ at magnification sizes 10000x, 11000x, and 12000x revealed small discontinuities and a non-uniform distribution of particles and the binders. The particles phase is shown as a white phase, while the binder phase is the darker phase (Figs. 8 and 9). The wood chip particles are embedded within the amorphous matrix composed of randomly distributed in the matrix planar boundaries. The surface of the wood chip particles is rough, indicating that the compatibility between particles and the binders was not as good as the bond in sample B, but the wood chip particles were not detached from the binder surface (Fig. 8).

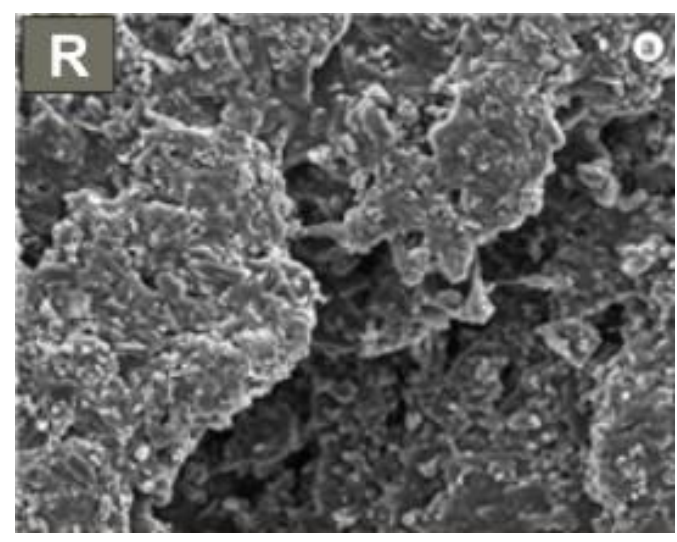

Fig. 8. SEM images of sample $R$ at magnification $\times 12000$

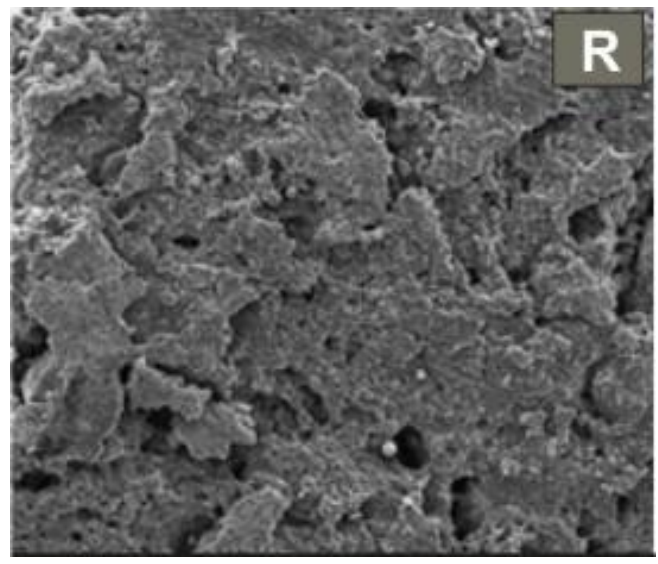

Fig. 9. SEM images of sample $R$ at magnification $\times 11000$

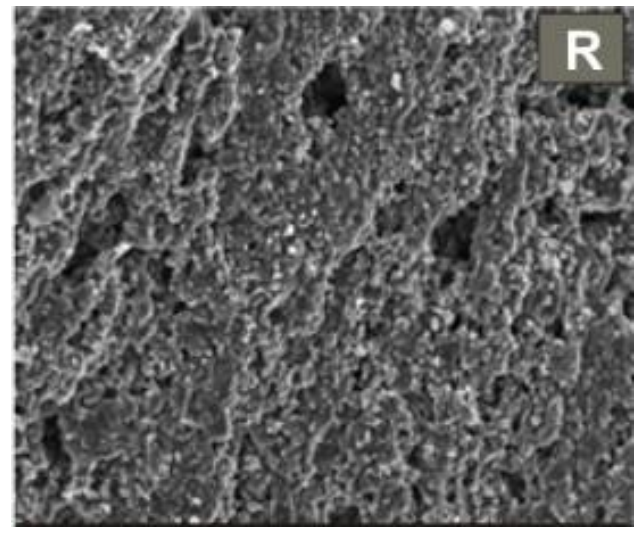

Fig. 10. The EDS analysis result of sample $R$ 


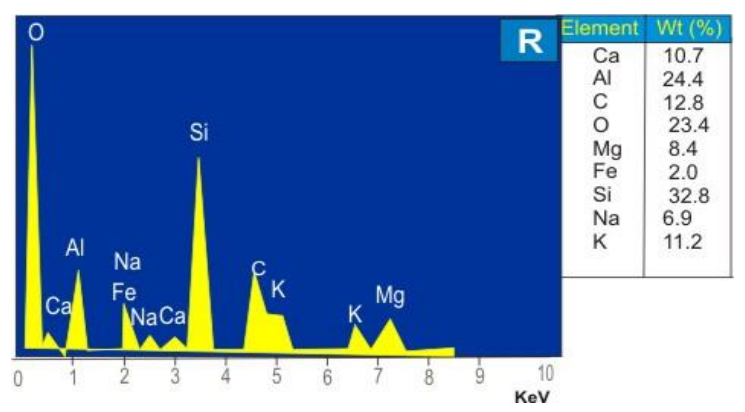

Fig. 11. SEM images of sample $R$ at magnification $\times 10000$

The EDS analysis result for sample $\mathrm{R}$ shows that the major elements in the composition are calcium, aluminium, carbon, oxygen, silicon and potassium (Fig. 10), while the minor components are magnesium, iron, and sodium (Fig. 11). The EDS analysis of the two samples was similar, but sample B has sulphur and oxygen.

\section{CONCLUSIONS}

1. The production of particleboard from the materials was found to be technically feasible.

2. The modification of cassava starch with glutaraldehyde improved the mechanical properties of the particleboard and the water absorption, but caused increased the thickness swelling of the samples.

3. The cassava starch and wood chips can be considered as an alternative for raw material in the manufacture of particleboard used in indoor environment due to moderate mechanical properties and low water absorption.

\section{REFERENCES CITED}

Akpenpuun, T. D., Adeniran, K. A., and Okanlawon, O. M. (2017). "Rattan cane reinforced concrete slab as a component for agricultural structures," Nigerian Journal of Pure and Applied Sciences 30(1), 3007-3014. DOI: 10.19240/njpas.2017.A20

Amini, M., Hazim, M., Hashim, R., Sulaiman, N. S., Hiziroglu, S., Sulaiman, O., Mohamed, M., Sarmin, S. N., Masri, M. N., Sulaiman, M. Z., and Bakar, B. A. (2016). "Effect of urea formaldehyde addition to the dimensional stability of particleboard made using glutardialdehyde modified corn starch as binder with FT-IR analysis," Materials Science Forum 840, 108-111. DOI: 10.4028/www.scientific.net/msf.840.108

ASTM D 1037-23 (2012). "Test methods for evaluating properties of wood-base fibre and particle panel materials," ASTM International, West Conshohocken, PA.

ASTM E986 - 04 (2017). "Practice for scanning electron microscope beam size characterisation," ASTM International, West Conshohocken, PA.

Baishya, P., and Maji, T. K. (2014). "Studies on effects of different cross-linkers on the properties of starch-based wood composites," ACS Sustainable Chem. Eng. 2, 17601768. DOI: $10.1021 /$ sc5002325 
Bardak, S., Nemli, G., Sari, B., Baharoglu, M., and Zekovic, E. (2010). "Manufacture and properties of particleboard composite from waste sanding dusts," High Temperature Materials and Processes 29, 159-168.

Bardak, S., and Nemli, G., (2018). "Use of screening machine wastes for manufacturing of particleboard composite," Journal of Bartin Faculty of Forestry 20(1), 81-86.

Chung, M. J., and Wang, S. Y. (2019). "Physical and mechanical properties of composites made from bamboo and woody wastes in Taiwan," Journal of Wood Science 65(1), 57-68. DOI: 10.1186/s10086-019-1833-1

Cravo, J. C. M., Sartori, D. d. L., Mármol, G., Schmidt, G. M., Balieiro, J. C. d. C., and Fiorelli, J. (2017). "Effect of density and resin on the mechanical, physical and thermal performance of particleboards based on cement packaging," Construction and Building Materials 151, 414-421.

Dumitrascu, A-E., Lunguleasa, A., Salca, E-A., and Ciobanu, V. D. (2019). "Evaluation of selected properties of oriented strand boards made from fast growing wood species," BioResources 15(1), 199-210. DOI: 10.15376/biores.15.1.199-210

Elbadawi, M., Osman, Z., Paridah, T., Nasroun, T., and Kantiner, W. (2015). "Mechanical and physical properties of particleboards made from ailanthus wood and UF resin fortified by acacias tannins blend," Journal of Materials and Environmental Science 6, 1016-1021.

Fiorelli, J., Bonilla, S. B., and Cabral, R. M. (2019). “Assessment of multilayer particleboards produced with green coconut and sugarcane bagasse fibers," Construction and Building Materials 205(1-9), 1.

DOI:10.1016/j.conbuildmat.2019.02.024

Guler, C., and Büyüksarı, Ü. (2011). "Effect of production parameters on the physical and mechanical properties of particleboards made from peanut (Arachis hypogaea 1.) hull," BioResources 6(4), 5027-5036. 10.15376/biores.6.4.5027-5036

Laleicke, P. F. (2018). "Wood waste, the challenges of communication and innovation," BioResources 13(2), 2182-2183. DOI: 10.15376/biores.13.2.2182-2183

de Melo, R. R., Stangerlin, D. M., Robinson, R., Santana, C. and Pedrosa, T. D. (2014). "Physical and mechanical properties of particleboard manufactured from wood, bamboo and rice husk," Materials Research 17(3), 682-686. DOI: 10.1590/s151614392014005000052

Kalaycioglu, H., and Nemli, G. (2006). "Producing composite particleboard from kenaf (Hibiscus cannabinus L.) stalks," Industrial Crops and Products 24(2), 177-180.

Mohd, H., Mohamad, A., Rokiah, H., Salim, H., Nurul, S. S., and Othman, S. (2013). "Properties of particleboard made from rubberwood using modified starch as a binder," Composites Part B (50), 259-264. DOI: 10.1016/j.compositesb.2013.02.020

Nakanishi, E. Y., Cabral, M. R., Fiorelli, J., Christoforo, A. L., Goncalves, P. d. S., and Holmer, S. J. (2019). "Latex and rosin films as alternative waterproofing coatings for 3-layer sugarcane-bamboo-based particleboards," Polymer Testing 75, 284-290.

Nemli, G., Kırc1, H., Serdar, B., and Ay, N. (2003). "Suitability of kiwi (Actinidia sinensis Planch.) prunings for particleboard manufacturing," Industrial Crops and Products 17(1), 39-46.

Onuegbu, T. U. (2010). "Improving fuel wood efficiency in rural Nigeria (a case of briquette technology)," International Journal of Chemistry in Nigeria 3(4), 35-43.

Sari, B., Nemli, G., Bardak, S., Baharoglu, M., and Zekoviç, E. (2010). "Effects of formaldehyde/urea mole ratio, panel density, shelling ratio, and waste screen dust on 
the physical and mechanical properties, and formaldehyde emission of particleboard composite," High Temperature Materials and Processes 29, 287-294.

Tascioglu, C., Umemura, K., Kusuma, S., Kose, C., Yalcin, M., Akcay, C., and Yoshimura, T. (2020). "Mold and larvae resistance of wood-based composites incorporating sodium fluoride," BioResources 15(1), 20-27. DOI: 10.15376/biores.15.1.20-27

Wang, S. Y., Yang, T. H., Lin, Y. T., Lin, C. J., and Tsai, M. J. (2007). "Fire-retardanttreated low-formaldehyde-emission particleboard made from recycled wood-waste," Building and Environment 42(7), 2472-2479. DOI: 10.1016/j.biortech.2007.03.047

Yang, S., Wu, J.-Q., Zhang, Y., Yuan, T.-Q., and Sun, R.-C. (2015). 'Preparation of lignin-phenol-formaldehyde resin adhesive based on active sites of technical lignin," Journal of Bio-based Materials and Bioenergy 9, 1-7. DOI: 10.1166/jbmb.2015.1514

Zhang, J., Kang, H. J., Gao, Q., Li, J., Pizzi, A., and Delotte, L. (2014). “Performance of larch (Larix gmelini) tannin modified urea-formaldehyde (TUF) resin and plywood bonded by TUF resin," Journal of Applied Polymer Science 131(22), Article ID 41064. DOI: 10.1002/app.41064

Article submitted: November 28, 2019; January 15, 2020; Revised version received and accepted: January 25, 2020; Published: January 28, 2020.

DOI: $10.15376 /$ biores.15.1.1861-1876 